\title{
Eficiência de Diferentes Marcas de Água Sanitária Na Higienização de Alfaces
}

Marly Silveira Santos (I), Rebeca Ayala Rosa da Silva (I,II), Fernanda de Souza Bernandes (I), Elaine Araújo de Carvalho (I), Nayara Alves Reis (I), Fabio Oliveira Santos (I), Norma Suely Evangelista Barreto (I)

(I) UFRB - Universidade Federal do Recôncavo da Bahia (Rua Rui Barbosa, 710, Centro - Cruz das Almas - Bahia. CEP 44.380-000), (II) UFBA - Universidade Federal da Bahia ( Av. Adhemar de Barros, no 500, Ondina, Salvador - Bahia. CEP: 40.170-110.)

\section{Resumo}

Dentre as hortaliças cruas consumidas pela população brasileira a alface (Lactuca sativa L.), se destaca por possuir valores nutricionais, sendo rica em vitaminas e minerais, além de auxiliar na perda de peso. No processo de higienização das hortaliças, o saneante mais utilizado e recomendado pela legislação brasileira é o hipoclorito de sódio, que contribui para a inocuidade do alimento, reduzindo os patógenos relacionados às Doenças Veiculadas por Alimentos (DVAs). O presente estudo objetivou avaliar a eficiência de três marcas de água sanitária comercializadas nos supermercados de Cruz das Almas, Bahia, Brasil. O teste foi realizado em triplicata com as diferentes águas sanitárias identificadas como, SA, SB e SC. Os tratamentos foram compostos por: T1(1colher de sopa/8 $\mathrm{ml}$ de água sanitária), T2 (2 colheres de sopa/16 ml de água sanitária), T3 (3 colheres/24 ml de água sanitária) e T4 (1 colher de sopa/8ml de hipoclorito de sódio fornecido pelo Ministério da Saúde). Todos os tratamentos foram realizados em $1000 \mathrm{~mL}$ de água potável. Após a imersão da alface na água clorada por 15 minutos foi quantificada a presença de bactérias heterotróficas mesófilas aeróbicas e coliformes a $45^{\circ} \mathrm{C}$. A contagem de bactérias mesófilas aeróbias cultiváveis e coliformes a $45^{\circ} \mathrm{C}$ na amostra controle (sem higienização) foi de log 5,7 UFC.g-1 a $\log$ 7,34 UFC.g-1

\footnotetext{
Referência:

Marly Silveira Santos, Rebeca Ayala Rosa da Silva, Fernanda de Souza Bernandes, Elaine Araújo de Carvalho, Nayara Alves Reis, Fabio Oliveira Santos, Norma Suely Evangelista Barreto.Eficiência de Diferentes Marcas de Água Sanitária $\mathrm{Na}$ Higienização de Alfaces. In: Anais do 12ㅇ Congresso Latinoamericano de Microbiologia e Higiene de Alimentos - MICROAL 2014 [= Blucher Food Science Proceedings, num.1, vol.1]. São Paulo: Editora Blucher, 2014.

DOI 10.5151/foodsci-microal-024
} 
para as bactérias mesófilas aeróbias e log 4,57 NMP.g-1 a log 5,3 NMP.g-1 para os coliformes a $45^{\circ} \mathrm{C}$. Tanto para os mesófilos, quanto para os coliformes a $45^{\circ} \mathrm{C}$, a maior redução da carga microbiana ocorreu com a água sanitária $\mathrm{SA}$, no tratamento $\mathrm{T} 1$, reduzindo 2 ciclos logarítmicos para os coliformes a $45^{\circ} \mathrm{C}(2,70$ NMP.g-1) e 3 ciclos logarítmicos para os mesofilos (4,17 UFC.g-1). Já para os tratamentos T2 e T3 houve a eliminação total de coliformes a $45^{\circ} \mathrm{C}$, com redução a níveis aceitáveis em torno de log (5 UFC.g-1) para os mesófilos cultiváveis. Entretanto, os valores de hipoclorito de sódio usados na higienização das hortaliças, ultrapassam os valores permitidos na legislação brasileira. Das três águas sanitárias utilizadas apenas a marca SA foi a que apresentou maior eficiência na redução de coliformes a $45^{\circ} \mathrm{C}$. Apesar das águas sanitárias testadas não reduzirem os coliformes a $45^{\circ} \mathrm{C}$ a níveis aceitáveis pela legislação vigente (log 2,0 NMP.g-1), o hipoclorito ainda é a melhora opção para a higienização das hortaliças.

Palavras-Chave: Alface, Cloro ativo, Coliformes, Higienização Agência de Fomento: 